\title{
Impact of Running Techniques through the Sprint Ability in Athletes during the COVID-19 Pandemic
}

\author{
Purwanto Purwanto $^{1}$, Ria Lumintuarso ${ }^{2}$, Erick Burhaein ${ }^{3, *}$ \\ ${ }^{1}$ Master Program of Sports Science, Postgraduates Program, Universitas Negeri Yogyakarta, Yogyakarta 55281, \\ Daerah Istimewa Yogyakarta, Indonesia \\ ${ }^{2}$ Faculty of Sports Science, Universitas Negeri Yogyakarta, Yogyakarta 55281, Daerah Istimewa Yogyakarta, Indonesia \\ ${ }^{3}$ Doctoral Program of Sports Education, School Postgraduates Studies, Universitas Pendidikan Indonesia, Bandung, 40154, Jawa Barat, \\ Indonesia
}

Received April 1, 2021; Revised May 7, 2021; Accepted June 15, 2021

\section{Cite This Paper in the following Citation Styles}

(a): [1] Purwanto Purwanto, Ria Lumintuarso, Erick Burhaein, "Impact of Running Techniques through the Sprint Ability in Athletes during the COVID-19 Pandemic," International Journal of Human Movement and Sports Sciences, Vol. 9, No. 4, pp. 717 - 724, 2021. DOI: 10.13189/saj.2021.090416.

(b): Purwanto Purwanto, Ria Lumintuarso, Erick Burhaein (2021). Impact of Running Techniques through the Sprint Ability in Athletes during the COVID-19 Pandemic. International Journal of Human Movement and Sports Sciences, 9(4), 717 - 724. DOI: 10.13189/saj.2021.090416.

Copyright $\odot 2021$ by authors, all rights reserved. Authors agree that this article remains permanently open access under the terms of the Creative Commons Attribution License 4.0 International License

\begin{abstract}
With the spread of the Covid-19 virus that is increasingly widespread, athletes cannot train optimally. This study aims to determine the effect of sprint running techniques on the ability of the 100-meter sprint in athletes during the COVID-19 pandemic. The method in this study was a true experiment with a pretest-posttest control group design. The total participants were 38 male athletes with an age range of $15-18$ years $(\mathrm{M}=17.3$; SD: 1.26). Data analysis in this study is descriptive analysis and hypothesis testing. The results of the study are: 1) For the control group, the H0 (not significant) statement "There is no effect and difference of sprint running technique on the athlete's 100 meters running ability", is not rejected. Then, there was a decrease in the mean of 0.23 or $1.78 \%$; 2) For the experimental group, the H1 (significant) statement "There is an effect of sprint running technique on the athlete's 100-meter running ability during the COVID-19 pandemic ", is not rejected. Then supported by an increase in the mean of 0.44 or $3.42 \%$, the conclusion is that there is an effect of sprint running techniques on the ability of the 100-meter sprint in athletes. This finding can have implications, namely being a reference for coaches or teachers in compiling training programs to improve the achievement of the 100-meter sprints in athletic sports during the COVID-19 pandemic. Further researchers should be able to modify other types of exercise and conduct research with a wider sample and population and
\end{abstract}

add different variables.

Keywords Running Technique, 100-Meter Sprint, Sprinter Athlete, Athletics, COVID-19

\section{Introduction}

With the spread of the Covid-19 virus, which is increasingly widespread, athletes cannot train optimally. The Covid-19 case first appeared at the end of 2019, this virus is dangerous for humans because it attacks the severe acute respiratory system [1], [2]. This virus quickly spread throughout the world and was designated a pandemic by the World Health Organization. This situation causes all activities in various fields that should be running to be stopped, including sports activities [3], [4]. For this reason, online learning and independent home training activities are carried out to maintain fitness and increase stamina with limited tools, of course, by following health protocols during this pandemic.

During this pandemic, athletes generally undertook independent training as an alternative at this time. Independent training is an exercise that can be done individually using tools or not, done to achieve good individual goals, society including athletes is forced to 
find ways how to train independently [5], [6]. How can athletes prepare themselves independently, and be able to maintain body fitness independently? Independent training is very beneficial for health during the current Pandemic or Covid 19 outbreak.

The 100-meter sprint is one of the events that are contested in short distance running in athletics [7], [8]. The 100-meter sprint is a run in which the athlete must cover the entire 100-meter distance at the maximum possible speed [7], [9]. For that athletes must be able to run as fast as possible by exerting all their speed from the start (starting from the start) to crossing the finish line [7].

Running a $100 \mathrm{~m}$ sprint is a forward movement that is endeavored to reach the goal (finish) as quickly as possible or in the shortest possible time [10], [11]. So, it can be said that the 100 meter sprint is a run that is attempted or carried out as fast as possible (maximum speed) from the start point to the finish in the shortest time possible to cover a distance of 100 meters.

Speed plays a very important role in reaching the finish line. The essence of the $100 \mathrm{~m}$ sprint achievement lies in running speed [9], [12]. Speed is the result of a period of work [7], [13]. Physically, speed is defined as the distance to time, whereas physiologically, speed is defined as the ability based on the ability to move [9], [14].

The COVID-19 pandemic that is currently occurring worldwide has an impact on all aspects of life, including sports clubs, especially in athletics [15], [16]. All activities are subject to strict health protocols, including sports training, including 1) Sports activities involving large numbers of people are suspended due to government policies to limit crowds, and; 2) Sports clubs cannot immediately revive even though they are allowed to run with strict health protocols, this is because the competition is not ready and the lack of sponsorship [1], [17]-[19]. This condition must be addressed by athletes by training independently to maintain their physical abilities, especially the ability to sprint 100 meters.

The success of the 100-meter sprint runner lies in the use of maximum force to push the body forward, knee height, and placing the foot just below the point of weight [20]. The speed of short-distance runners also depends on the athlete's ability to combine the strength of the legs, upper arms, forearms, palms, torso, and other parts in one coordination [21], [22]. Also, the determining factors for a short runner are the strength of the muscles worked, the length of the legs, the frequency of movement, and the perfect running technique.

One of the most important basic factors in determining your 100-meter running speed is the perfect running technique [21]. Increasing the achievement of sprint 100-meter requires improvement and development of technical elements in sprinting. The use of the good technique will increase efficiency so that the 100 -meter sprint achievement can be improved.

A good 100-meter sprint athlete needs to master the basic techniques of running. 100-meter sprint athletes who have good basic technique tend to good perform [23]. There are three basic techniques for sprinting, namely the squatting start, running movements, and techniques for entering the finish line [21]. The goal of a 100-meter sprint is to do horizontal speed with the maximum 100 -meter distance and as fast as possible as a result of the body pushing forward [24]. The $100 \mathrm{~m}$ sprint run consists of several stages, namely the reaction and boost stage, the acceleration stage, the transition stage, the maximum speed stage, the speed maintenance stage, and the finish stage. Starting techniques and running techniques are very important aspects because they form the basis for sprinting or sprinting. The basic technique of running the 100-meter sprint aims to learn the systematic basics of sprinting [21], [25].

100-meter sprinter athletes generally make mistakes in running techniques, especially in footsteps such as thighs not lifting when the footsteps and steps are still too short or not optimal. This results in increased running speed that is less fast and results in slower time [11], [26]. This is the importance of why it is necessary to overcome sub-optimal footsteps.

When running, the technique of the footsteps of the 100 $\mathrm{m}$ sprint athlete must be longer and maximum, the thighs are raised more or at least closer to the hips so that a better running pace is created [2], [27]. When running fast, it is balanced with maximum and balanced hand swings, so that it can help increase running speed. Efforts to improve basic sprint techniques must pay attention to training principles for increasing the progress of the $100 \mathrm{~m}$ sprint. 


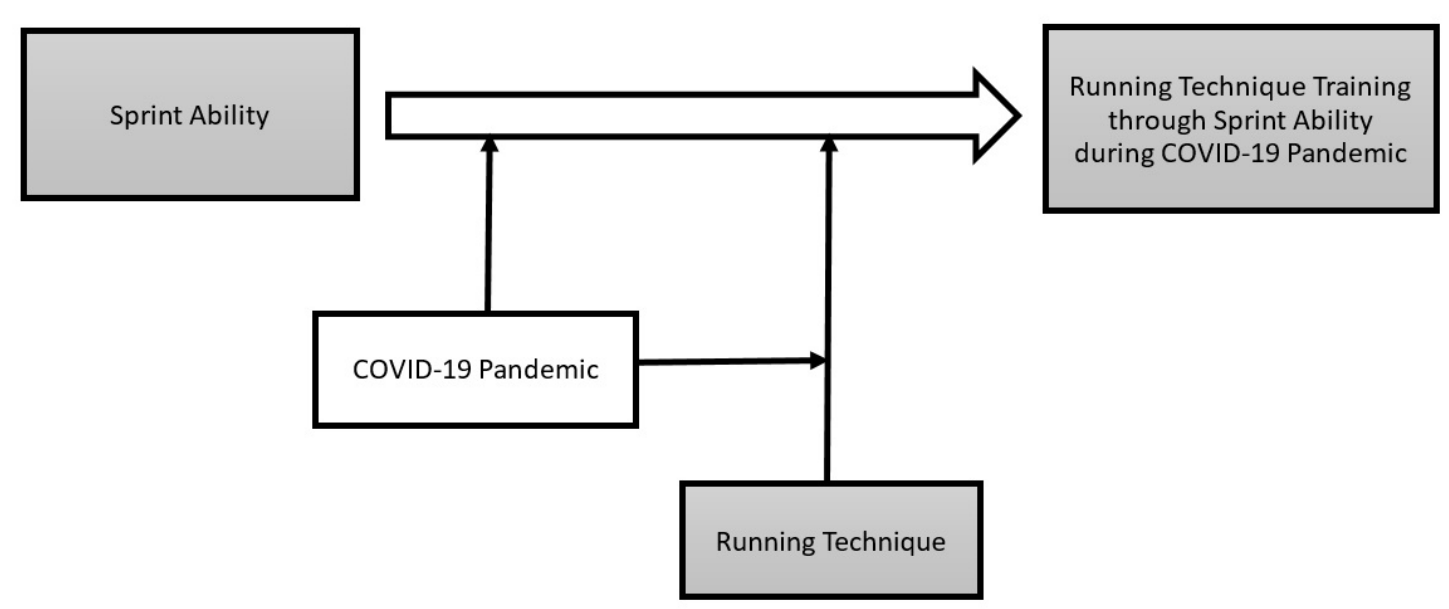

Figure 1. Gap Analysis of the Problem

The exposure conditions mentioned above certainly provide a major problem gap in athlete's sprint ability in the midst of the current COVID-19 pandemic. The main problem can theoretically be overcome with training in running techniques, which of course takes into account the conditions of the COVID-19 pandemic. Therefore, it is interesting to explore more about the impact of running technique training on sprinting ability during the COVID-19 pandemic.

\section{Materials and Methods}

\subsection{Research Method}

This study used a quantitative research approach, then the design used was a true experimental research design with a pretest-postest control group design [13], [28]. The research design is as shown in Table 1 as follows.

Table 1. True experiment pretest-postest control group design

\begin{tabular}{|c|c|c|c|c|}
\hline Treatment Group & $\mathrm{M}_{1}$ & $\mathrm{O}_{1}$ & $\mathrm{X}$ & $\mathrm{O}_{2}$ \\
\hline Control Group & $\mathrm{M}_{2}$ & $\mathrm{O}_{1}$ & $\mathrm{C}$ & $\mathrm{O}_{2}$ \\
\hline
\end{tabular}

Information:

$\mathrm{M}_{1}$ : The subjects of the treatment group with randomized

$\mathrm{M}_{2}$ : The subjects of the control group

$\mathrm{O}_{1}$ : Pretest

$\mathrm{X}$ : Providing treatment

$\mathrm{C}$ : Without treatment

$\mathrm{O}_{2}$ : Postest

\subsection{Participant}

Participants in this study used 38 male athletes with an age range of 15-18 years $(\mathrm{M}=17.3$; $\mathrm{SD}$ : 1.26). Participants were divided into two groups without being randomized, namely 19 athletes as the treatment group and 19 athletes as the control group. Participants in this study will undergo a series of studies including 1) pretest; 2) treatment, and; 3) posttest. All activities have followed health protocols according to the conditions of the COVID-19 pandemic, so that activities, both treatment and measurement tests, are conditioned to be carried out in the participant's home environment. The conditions for a place that must be fulfilled besides being close are outdoor fields or indoor fields that meet the $100 \mathrm{~m}$ long standard. This is because later it will be used to test the $100 \mathrm{~m}$ sprint ability. Treatment group participants underwent an exercise program with guidance from researchers while observing the health protocols that were established during the COVID-19 pandemic.

\subsection{Instruments}

The research instrument used in this study was a 100-meter sprint speed test [29]. The participants ran a sprint from the start point to finish as far as 100-meter. Measurements using a stopwatch with standardized units of time. All study participants conducted the test independently with the provisions and guidelines of the researcher. The stipulation is that the participants/athletes are assisted by an examiner (preferably with the fellow athletes closest to their place of residence).

\subsection{Data Collection Technique}

The data collection techniques in this study were carried out by tests and measurements. The data collection process begins with giving an explanation of the test implementation and warming up. Data were collected 2 times, namely at the beginning of the study (pretest) and the end of the study (posttest). Measurements (pretest \& posttest) using a stopwatch with standardized units of time for the 100 meters sprint test in the indoor room. Especially for the treatment group, after doing the pretest they followed the process of training activities.

The process of training activities in this study was carried out in 18 meetings in an indoor room. The process of training 18 times can be said to be trained because there have been permanent changes. Exercises in the sand in this study were carried out 4 times a week, namely on 
Tuesday, Thursday, Saturday, and Sunday. The training will be held on Monday and Thursday from 15.30-17.00 WIB. Then Saturdays and Sundays are held at 06.00-08.00 WIB. Athletes in the treatment group followed a jump training program with rules based on theoretical standards in training, including:

1. Training load and speed of explosive training [22], [30] with an intensity of about $50-75 \%$, the number of sets of 4-6, then intervals of 2-5 minutes, while the rhythm of the training is explosive/fast.

2. Maximum Repetition Calculation (RM) is the athletes/participants doing sprints with a time limit of 30 seconds [22].

3. The frequency of exercise in the treatment group was carried out with a duration of 6 weeks and a frequency of training 3 times a week [22].

4. The increase in training load is calculated every 2 weeks using the RM return test [22].

5. The increase in expenses is individual [22].

\subsection{Data Analysis}

Data analysis in this study is descriptive analysis and hypothesis testing. Descriptive analysis reveals descriptive data about the control and experimental groups. The prerequisite analysis test included the normality and homogeneity test, then test the research hypothesis using the t-test. The research hypothesis is as follows:

Hypothesis $0(\mathrm{H} 0)$ : There is no effect and difference of sprint running techniques on the ability of the 100 Meter Sprint in athletes during the COVID-19 pandemic.

Hypothesis 1 (H1): There is an effect and difference of sprint running techniques on the ability of the 100 Meter Sprint in athletes during the COVID-19 pandemic.

\section{Results}

\subsection{Results of Descriptive Data of the Control Group Pretest and Posttest}

The results of the descriptive statistics for the pretest and posttest of the athlete's 100-meter running ability in the control group $(\mathrm{n}=19)$ can be seen in table 2 .

Table 2. Statistics Descriptive of the 100-meter running ability of the control group athletes

\begin{tabular}{ccc}
\hline Descriptive statistics & Pretest & Posttest \\
\hline Mean & 12.93 & 13.16 \\
\hline Median & 13.16 & 13.21 \\
Mode & 11.29 & 11.67 \\
\hline Std. Deviation & 1.09 & 1.12 \\
\hline Minimum & 11.28 & 11.67 \\
Maximum & 14.42 & 14.60 \\
\hline The difference in Mean (time) & \multicolumn{3}{c}{$(+) 0.23$} \\
\hline Percentage of Decrease (speed) & \multicolumn{3}{c}{$1.78 \%$} \\
\hline
\end{tabular}

The results of the description show that the pretest to a posttest Mean (time) from 12.93 increases to 13.16. This means that there is an increase in time 0.23 which means that the speed decreases $1.78 \%$. This means that when viewed from the comparison of the mean, athletes in the control group experienced a decrease (speed) in their ability to sprint 100 meters. Further hypothesis testing is needed to strengthen these findings.

\subsection{Results of the Experimental Group Pretest and Posttest Descriptive Data}

Table 3. Descriptive statistics of the experimental group athlete's 100-meter run ability

\begin{tabular}{ccc}
\hline Descriptive statistics & Pretest & Posttest \\
\hline Mean & $12 . .86$ & 12.42 \\
\hline Median & 12.48 & 12.34 \\
\hline Mode & 11.28 & 11.07 \\
\hline Std. Deviation & 0.99 & 0.98 \\
\hline Minimum & 11.28 & 11.07 \\
\hline Maximum & 11.42 & \\
The difference in Mean (time) & & $(-) 0.44$ \\
\hline Percentage of Increase (speed) & & $3.42 \%$ \\
\hline
\end{tabular}

The results of the descriptive statistics for the pretest and posttest of the athlete's 100-meter running ability in the experimental group $(\mathrm{n}=19)$ can be seen in table 3 . The results of the description show that the mean pretest to posttest (time) from 12.86 decreased to 12.42 . This means that there was a decrease in time 0.44 which means that the speed increased by $3.42 \%$. This means that when viewed from the comparison of the mean, the athletes in the experimental group experienced an increase (speed) in the ability to sprint 100 meters. Further hypothesis testing is needed to strengthen these findings.

\subsection{Prerequisite Analysis Test}

3.3.1. Normality test

Table 4. Normality Test Results

\begin{tabular}{cccc}
\hline Normality test & Shaphiro-Wilk & Sig. & Ket \\
\hline $\begin{array}{c}\text { Control Group - } \\
\text { Pretest }\end{array}$ & 0.925 & 0.484 & Normal \\
\hline $\begin{array}{c}\text { Control Group - } \\
\text { Posttest }\end{array}$ & 0.934 & 0.601 & Normal \\
\hline $\begin{array}{c}\text { Experiment Group - } \\
\text { Pretest }\end{array}$ & 0.894 & 0.186 & Normal \\
\hline $\begin{array}{c}\text { Experiment Group - } \\
\text { Posttest }\end{array}$ & 0.906 & 0.314 & Normal \\
\hline
\end{tabular}

The purpose of the normality test is to find out whether the data obtained from the test results follows the normal distribution pattern or not. The variable normality test was carried out with the Shaphiro-Wilk. The rule used to 
determine whether a distribution is normal or not is if the significant value is greater than 0.05 (significant> 0.05), then normal and if the significant value is less than 0.05 (significant $<0.05$ ) it is said to be abnormal [31]. The normality test can be seen in Table 4 .

Based on Table 4 above, it can be seen that the overall significance values are all greater than 0.05 (significant> 0.05 ) in the sprint ability data (pretest-posttest control and pretest-postest experiment), so the hypothesis which states that the data are normally distributed is accepted.

\subsubsection{Homogeneity Test}

The purpose of the homogeneity test is to determine whether the data obtained from the test results follow a homogeneous distribution pattern or not. Variable homogeneity test was done by using Levene Statistic. The rule used to determine whether a distribution is normal or not is if the significant value is greater than 0.05 (significant $>0.05$ ), then homogenous and if the significant value is less than 0.05 (significant $<0.05$ ) it is said to be inhomogeneous [31]. The homogeneity test can be seen in Table 5 below:

Table 5. Homogeneity Test Results

\begin{tabular}{cccc}
\hline Homogeneity Test & $\begin{array}{c}\text { Levene } \\
\text { Statistic }\end{array}$ & Sig. & Ket \\
\hline Sprint Ability & & & \\
\hline $\begin{array}{c}\text { Control Group (Pretest - } \\
\text { Posttest) }\end{array}$ & 2.455 & 0.115 & Homogenous \\
\hline $\begin{array}{c}\text { Experiment Group } \\
\text { (Pretest - Posttest) }\end{array}$ & 1.455 & 0.206 & Homogenous \\
\hline
\end{tabular}

Based on Table 5 above, it can be seen that the overall significance values are all greater than 0.05 (significant> 0.05 ) in the sprint ability data (pretest-posttest control and pretest-posttest experiment), so the hypothesis which states that the data are homogeneous is accepted.

\subsection{Hypothesis Testing (Effect \& Difference)}

The results of the t-test pretest and posttest of the control group, as well as the experimental 100-meter running ability of the athletes, are presented in Table 6 . After the t-test results are known, it is followed by hypothesis testing of the control and experimental groups.

Table 6. Hypothestinting Testing (Effect \& Difference)

\begin{tabular}{cccc}
\hline Pretest - Posttest & t & df & Sig. (2-tailed) \\
\hline Control Group & 1,877 & 18 & 0.010 \\
\hline Experiment Group & 3.753 & 18 & 0.000 \\
\hline
\end{tabular}

Based on the calculation of pretest and posttest data in the control group on the ability to run the 100-meter sprint, the value of $\mathrm{p}=0.010$ was obtained, meaning that $\mathrm{p}>$ 0.005 so that $\mathrm{H} 0$ was accepted and $\mathrm{H} 1$ was rejected. So for the control group, the H0 (not significant) statement "There is no effect and difference of sprint running techniques on the ability of the 100-meter Sprint in athletes during the COVID-19 pandemic", is not rejected.

Based on the calculation of pretest and posttest data in the experimental group on the ability to run the 100-meter sprint, the value of $p=0.000$ is obtained, meaning that $p$ $<0.005$, so H0 is rejected and H1 is not rejected (accepted). So for the experimental group, the H1 (significant) statement "There is an effect of sprint running techniques on the ability of the 100-meter Sprint in athletes during the COVID-19 pandemic ", is not rejected.

\section{Discussion}

The results showed that technical training had a significant impact on the ability to sprint 100-meter during the COVID-19 pandemic. This means that this technical training method is very suitable for use by athletes during the COVID-19 pandemic, even though it is done independently.

A 100-meter sprint is a sprint with a distance of 100-meter [32]. The speed in the 100-meter sprint produces strong and fast contraction of the muscles which is converted into a smooth, efficient motion that is indispensable for runners to achieve high speed. The goal of a sprint is to do the maximum and fastest possible horizontal speed that results from the body pushing forward. Short distance running consists of several stages, namely the reaction and boost stage, the acceleration stage, the transition stage, the maximum speed stage, speed maintenance, and finish. The speed component is one of the most important factors for all athletic numbers, especially the 100-meter sprint [33].

To achieve this goal in a sprint event, the athlete must focus on achievement and maintaining maximum running speed [32]. As it is well known that the most obvious requirement of all sprints is speed. Speed in sprinting is the result of strong and fast contraction of the muscles, converted into a smooth, efficient movement, this activity is required in running at high speed.

Many of the characteristics of the human body play a large role in the 100 -meter run ability. The skill of running 100 meters seems simple, it depends on the ability of an athlete to combine movements of the legs, arms, body, and so on throughout in a smoothly coordinated manner.

We have to consider aspects of human anatomies, such as height, frequency, stride, stride length, speed, energy production, somatotype, anthropometry, power, and muscle fiber composition, when analyzing a 100-meter run [32]. It should also take into account external contributing factors such as footwear, injury history, running performance, and variation in horizontal power, if we analyze the running motion within 100-meter.

A running speed is determined by stride length and stride frequency [32]. The optimal stride length is largely 
determined by the physical properties and by the force applied to each stroke. The main requirement of sprinting is speed, speed in sprinting is from strong, fast contractions of the muscles which are converted into smooth, smooth, and efficient movements that are needed to be able to run at high speeds. The 100-meter run that is achieved 9-10 seconds requires perfect technique and arrangement of running elements, the slightest mistake will reduce the result of the time achieved.

What can be learned, trained, and developed is the need for skill or dexterity and the techniques involved in converting muscle contractions into efficient movements from a good sprint [32]. The training of the sprint running techniques can improve other biomotor abilities such as strength, flexibility, coordination, and special endurance that contribute to a successful sprint. Previous research on the effect of sprint running techniques on the ability to run 100 meters, can see in Table 5 .

Sprint technique is one aspect that affects sprint ability, especially the 100 -meter number. The Sprint technique is at the core of these factors because it is integrated with other factors [32]. According to the IAAF [32], The factors that play a role in sprint running achievement are described in Figure 2.

Table 5. Previous research on the effect of sprint running techniques on the ability to run 100 meters

\begin{tabular}{ccc}
\hline Researcher & Title & Relevance of Findings \\
\hline Bezodis, et al [23] & $\begin{array}{c}\text { Sprint Running Performance and Technique } \\
\text { Changes in Athletes During Periodized Training: } \\
\text { An Elite Training Group Case Study }\end{array}$ & $\begin{array}{c}\text { The sprint technique influences the results of the } \\
\text { athlete's sprint ability. }\end{array}$ \\
\hline Rumpf, et al [34] & $\begin{array}{c}\text { Effect of Different Training Methods on Running } \\
\text { Sprint Times in Male Youth }\end{array}$ & $\begin{array}{c}\text { The training method in improving running } \\
\text { technique will improve and affect the sprint time. }\end{array}$ \\
\hline Maćkała, et al [27] & Selected Determinants of Acceleration in the \\
100m Sprint & $\begin{array}{c}\text { One aspect that affects the sprint acceleration of } \\
\text { 100-meter is the use of the right running } \\
\text { technique. }\end{array}$ \\
\hline Majumdar \& Robergs [35] & $\begin{array}{c}\text { The Science of Speed: Determinants of } \\
\text { Performance in the 100-meter Sprint }\end{array}$ & $\begin{array}{c}\text { The performance of the 100-meter sprint ability is } \\
\text { influenced by the sprinter running technique. }\end{array}$ \\
\hline Morin, et al [36] & Mechanical determinants of 100-meter sprint \\
running performance & $\begin{array}{c}\text { The 100-meter sprint performance works in } \\
\text { synergy with motion mechanics and is closely } \\
\text { related to the sprint running technique. }\end{array}$ \\
\hline
\end{tabular}

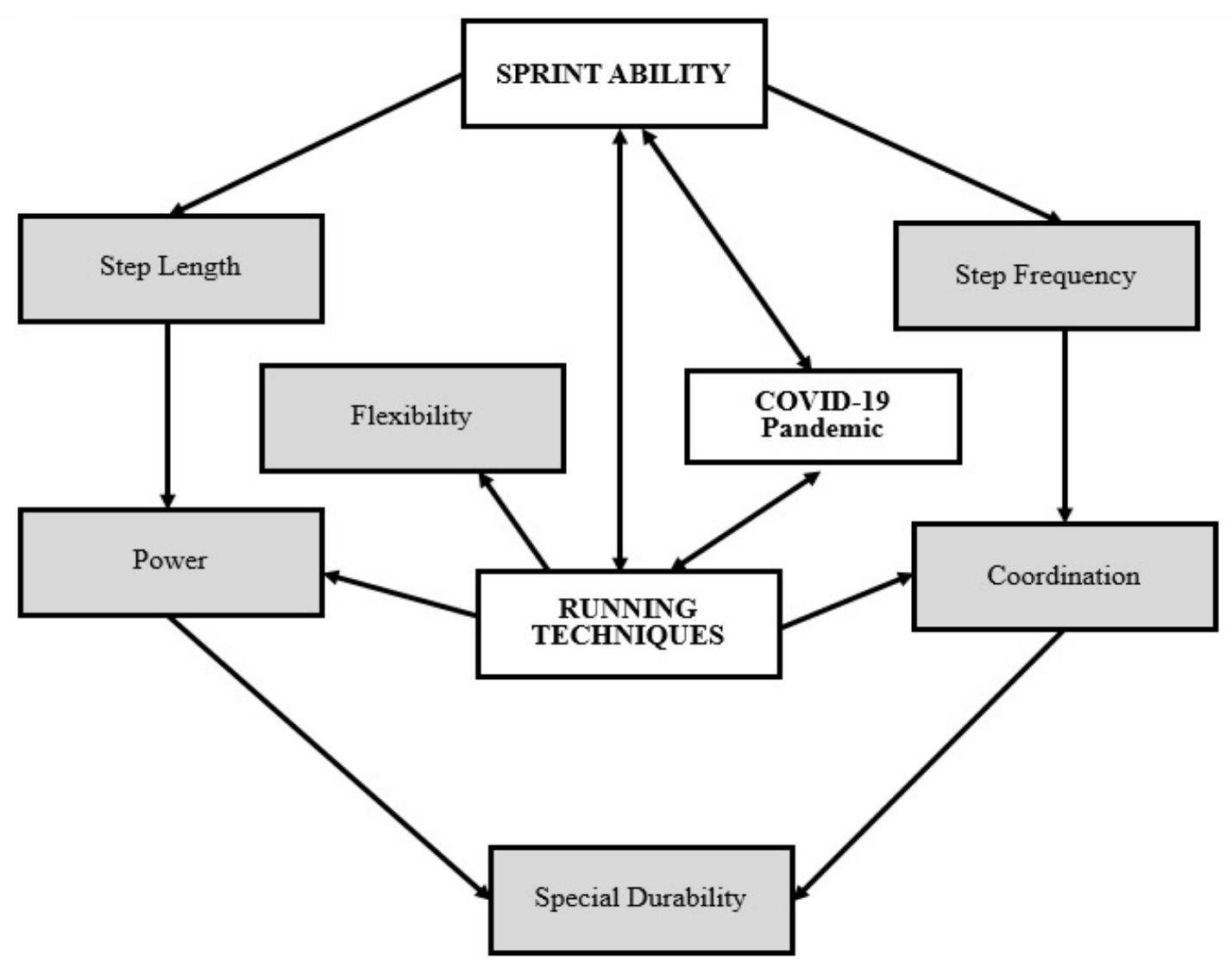

Figure 2. Parameters related running technique through sprint ability during pandemic COVID-19 
According to this chart, it is explained that sprint achievement is influenced by stride length and stride frequency. The stride length influencing factor is power. Good power needs to be aligned with running movements so that harmonizing the ability to use power is a technique and to get a stable stride length for a long time requires special endurance. The frequency of steps is influenced by the ability to coordinate movements; the better the coordination of the movements, the better the frequency of steps taken, the frequency of steps taken for a long time, special resistance is required. Good coordination is influenced by how the running movement technique is effective in its implementation so that these components affect each other's sprint running achievement. Good running technique is the main parameter related to the achievement of a sprint (100-meter) because this will also affect other parameters.

\section{Conclusions}

Based on the above conclusion, it is known that there is an effect of sprint running techniques on the ability of the 100-meter Sprint in athletes during the COVID-19 pandemic. This finding can have implications, namely being a reference for coaches or teachers in compiling training programs to improve the achievement of the 100-meter sprint in athletic sports.

This research has implications for the 100-meter sprinter trainer with the data the findings of this study can be used as a reference to improve their training activities to improve the performance of the sprinter athletes.

This research is not without limitations in its implementation. Limitations of the study include: 1) Researchers cannot control the activities of athletes outside of training which can affect test results, such as body conditions, psychological factors, and so on; and 2) The weather often changes drastically and the wind direction is unpredictable so that during the implementation of tests and exercises or treatment is quite constrained.

For further researchers, they should be able to modify other types of exercise and conduct research with a wider sample and population as well as the addition of different variables so that the treatment given to affect the performance of the 100-meter sprint can be identified more broadly in increasing the ability of sprinter athletes.

\section{Acknowledgments}

The author would like to thank all those who supported this research.

\section{Conflict of Interest}

All authors state that there is no conflict of interest in this study.

\section{REFERENCES}

[1] J. Wu and P. Zha, "Preventive, Mitigating, and Treatment Strategies for COVID-19," SSRN, vol. 2020, no. February 25, pp. 1-38, 2020.

[2] Y. M. Putra, S. Purwanto, and E. Burhaein, "Effect of Limb Muscle Power Training with Leaps on Athlete's Speed during the COVID-19 Pandemic," Int. J. Hum. Mov. Sport. Sci., vol. 9, no. 3, pp. 461 - 465, 2021. DOI: 10.13189/saj.2021.090310.

[3] WHO, "Physical activity: Impact," 2020. [Online]. Available:

https://www.who.int/health-topics/physical-activity\#tab=ta b_2. [Accessed: 12-Dec-2020].

[4] WHO, "Global recommendations on physical activity for health," $2020 . \quad$ [Online]. Available: https://www.who.int/dietphysicalactivity/factsheet_olderad ults/en/. [Accessed: 05-Jun-2020].

[5] W. B. Young, B. Dawson, and G. J. Henry, "Agility and change-of-direction speed are independent skills: Implications for training for agility in invasion sports," Int. J. Sport. Sci. Coach., vol. 10, no. 1, pp. 159-169, 2015.

[6] W. Sonchan, P. Moungmee, and A. Sootmongkol, "The Effects of a Circuit Training Program on Muscle Strenght, Agility, Anaerobic Performance and Cardiovascular Endurance," Int. J. Sport Heal. Sci., vol. 11, no. 4, pp. 176179, 2017.

[7] B. I. Balyi, "Long-term athlete development: Trainability in childhood and adolescence," Olympic Coach, vol. 16, no. 1, pp. 4-9, 2004.

[8] E. Burhaein, B. K. Ibrahim, and R. Pavlovic, "The Relationship of Limb Muscle Power, Balance, and Coordination with Instep Shooting Ability: A Correlation Study in Under-18 Football Athletes," Int. J. Hum. Mov. Sport. Sci., vol. 8, no. 5, pp. 265-270, 2020. DOI: 10.13189/saj.2020.080515.

[9] J. Baker, J. Fraser-thomas, R. A. Dionigi, and S. Horton, "Sport participation and positive development in older persons," Eur. Rev. Aging Phys. Act., vol. 7, no. 1, pp. 3-12, 2010.

[10] E. Burhaein, "Aktivitas Fisik Olahraga untuk Pertumbuhan dan Perkembangan Siswa SD," Indones. J. Prim. Educ., vol. 1, no. 1, pp. 51-58, 2017.

[11] T. Haugen, D. Mcghie, and G. Ettema, "Sprint running: from fundamental mechanics to practice-a review," Eur. $J$. Appl. Physiol., vol. 119, no. 5, pp. 1273-1287, 2019.

[12] E. Burhaein, "Aktivitas Permainan Tradisional Berbasis Neurosainslearning Sebagai Pendidikan Karakter Bagi Anak Tunalaras," J. Sport. J. Penelit. Pembelajaran, vol. 3, no. 1 , p. $55,2017$.

[13] D. T. P. Phytanza and E. Burhaein, "The Effects of Tenure, Teacher Certification, and Work Motivation on Special 
Needs Teacher Performance," Univers. J. Educ. Res., vol. 8 , no. 9 , pp. $4348-4356,2020$.

[14] D. T. P. Phytanza and E. Burhaein, "Aquatic activities as play therapy children autism spectrum disorder," Int. J. Disabil. Sport. Heal. Sci., vol. 2, no. 2, pp. 64-71, 2019.

[15] J. Woods et al., "The COVID-19 pandemic and physical activity," Sport. Med. Heal. Sci., vol. 2, no. 2, pp. 55-64, 2020.

[16] E. Burhaein, "Pembelajaran dalam Pandemi COVID-19: Mengapa Pendidikan Jasmani Adaptif Penting untuk Siswa Disabilitas di Sekolah Luar Biasa," in Disrupsi Strategi Pembelajaran Olahraga: Serta Tantangan dalam Menghadapi New Normal selama masapandemi Covid-19, Tulungagung: Akademia Pustaka, 2020, pp. 187-196.

[17] C. Brom, J. Lukavsky, D. Greger, and T. Hannemann, "Mandatory Home Education during the COVID-19 Lockdown in the Czech Republic: A Rapid Survey of 1 st -9 th Graders' Parents," Front. Educ., vol. 5, no. 103, pp. 1$11,2020$.

[18] S. Ravalli and G. Musumeci, "Coronavirus Outbreak in Italy: Physiological Benefits of Home-Based Exercise During Pandemic," J. Funct. Morphol. Kinesiol., vol. 5, no. 31, pp. 1-6, 2020.

[19] E. Burhaein, "Bagaimana Pendidikan Jasmani Adaptif di Era New Normal," in Bunga Rampai Strategi, Proses, Evaluasi, dan Model Pembelajaran Pendidikan Jasmani, Olahraga, dan Kesehatan (PJOK) pada Era Pandemi Covid-19, Surabaya: UNESA University Press, 2020.

[20] T. Haugen, S. Seiler, Ø. Sandbakk, and E. Tønnessen, "The Training and Development of Elite Sprint Performance: an Integration of Scientific and Best Practice Literature," Sport. Med., vol. 5, no. 1, pp. 44-59, 2019.

[21] T. Haugen, "Sprint Running Performance Monitoring: Methodological and Practical In press Sprint running performance monitoring: methodological and practical considerations," Sport. Med., vol. 46, no. 5, pp. 641-656, 2016.

[22] T. O. Bompa and C. Buzzichelli, Periodization Theory and Methodology of Training, Sixth. United States, 2019.

[23] I. N. Bezodis, D. G. Kerwin, and S. Cooper, "Sprint Running Performance and Technique Changes in Athletes During Periodized Training: An Elite Training Group Case Study," Int. J. Sports Physiol. Perform., vol. 13, no. 6, pp. $1-24,2017$.
[24] M. Otsuka, T. Kawahara, and T. Isaka, "Acute Response of Well-Trained Sprinters to a 100-m Race: Higher Sprinting Velocity Achieved With Increased Step Rate Compared With Speed Training," J. Strength Cond. Res., vol. 30, no. 3, pp. 635-642, 2016.

[25] E. Burhaein, D. T. P. Phytanza, and N. Demirci, "The development and validation of a revised Friendship Activity Scale and Adjective Checklist for use in the Indonesian Unified Sports program," Int. Sport. Stud., vol. 42, no. e, pp. 18-28, 2020.

[26] E. Burhaein, B. Tarigan, and D. T. P. Phytanza, "The experience and understanding of the K-13 curriculum implementation of Indonesian teachers of Adapted Physical Education (APE)," Int. Sport. Stud., vol. 42, no. e, pp. 2942, 2020.

[27] K. Maćkała, M. Fostiak, and K. Kowalski, "Selected Determinants of Acceleration in the $100 \mathrm{~m}$ Sprint," J. Hum. Kinet., vol. 45, no. 1, pp. 135-148, 2015.

[28] J. R. Fraenkel, N. E. Wallen, and H. H. Hyun, How to design and evaluate research in education. New York: Mc Graw Hill, 2012.

[29] Topend Sports, "Sprint or Speed Test," 2020. [Online]. Available:

https://www.topendsports.com/testing/tests/sprint.htm. [Accessed: 20-Jan-2020].

[30] J. Nossek, General theory of training. Logos: Pan African Press, 1982

[31] J. Sarwono, "PASW Statistics 18: Belajar Statistik Menjadi Mudah dan Cepat.” CV Andi Offset, Yogyakarta, 2010.

[32] IAAF, Level I/II Sprint \& Hurdles Textbook. Mo: International Association of Athletics Federations, 2001.

[33] IAAF, Competition rules. Monaco: International Association of Athletics Federations, 2009.

[34] M. C. Rumpf, J. B. Cronin, S. D. Pinder, J. Oliver, and M. Hughes, "Effect of Different Training Methods on Running Sprint Times in Male Youth," Pediatr. Exerc. Sci., vol. 24, no. 3, pp. 170-186, 2012.

[35] A. S. Majumdar and R. A. Robergs, "The Science of Speed: Determinants of Performance in the $100 \mathrm{~m}$ Sprint," Int. J. Sports Sci. Coach., vol. 6, no. 3, pp. 479-493, 2011.

[36] J.-B. Morin, M. Bourdin, P. Edouard, N. Peyrot, P. Samozino, and J.-R. Lacour, "Mechanical determinants of 100-m sprint running performance," Eur. J. Appl. Physiol., vol. 112, no. 11, pp. 3921-3930, 2012. 